\title{
THE EFFECT OF ATM SERVICE QUALITY ON CUSTOMER'S SATISFACTION AND LOYALTY: AN EMPIRICAL ANALYSIS
}

\author{
Sohail Khan ${ }^{\star}$, Dr. \\ Nabaz Nawzad Abdullah, Dr. \\ Lebanese French University, Kurdistan, Iraq \\ ${ }^{*}$ E-mail: sohailkhan@lfu.edu.krd
}

\begin{abstract}
Technology has made the life faster and easier. With the growth of technology, every sector has upgraded them to be competitive in the market. With the introduction of latest technology, customer satisfaction comes into picture. Banks are also using technology for satisfying the customers. The bank offers various services to their customer to satisfy them. Automated Teller Machine (ATM) services if one of them. Customer satisfaction is the prime objective of Banks. This research work is aspiring to examine the ramification of Automated Teller Machine (ATM) service qualities on overall customer satisfaction. Survey method was used to collect data. Information from 211 ATM users was collected from different places of Kurdistan region using a structured questionnaire. A pilot survey was conducted to ensure all dimensions meets to its objectives of research. SPSS-22 was used for analyzing the data. To recognize the service quality components of ATM and their association with overall customer satisfaction descriptive analysis, correlation and coefficient and regression test and ANOVA test were used. Results indicates that majority of dimensions are significantly correlated with overall customer satisfaction. At the end, few recommendations were made for improvement of ATM service quality.
\end{abstract}

\section{KEY WORDS}

ATM services dimensions, convenient, customer satisfaction, ease of use, fulfillment, reliability, responsiveness, security, privacy.

There have been enormous development and broadening in banking exercises in the course of the last one-and-a-half decades. Improvement of a sound and satisfactory information system has turned into a need to address the difficulties of development and expansion. ATM (Automated Teller Machine) Services is one of them. At the time of manual exchanges, an account holder needed to hang tight for a considerable length of time at the bank counters for getting his own cash. ATM is an autoelectronic monetary outlet, which empowers customers to complete essential exchanges in absence of an operator of the branch. ATM implies both going without cash and whenever cash. Availability of ATMs at major places like Malls, Hospital, Fuel Stations and other prime location helps the customers to save lot of time. An ATM allows a banks customer to conduct their banking transactions $24^{\star} 7$, i.e. non-stop banking. By observing the potential market in Erbil city outside banks likewise opened their financial administrations in the area. The major outside banks are BBAC, Byblos bank, Vakyfbank, Bank Asya, IBL Bank ${ }^{1}$. In spite of the nearness of various private banks, the State-owned banks dominate the Iraqi banking industry. The Iraqi financial part itself is made out of 7 state-claimed banks, which are by a long shot the most predominant performing artists in the division, and 47 private banks, 15 outside banks and 9 Islamic banks. Trade Bank of Iraq, Rafidain Bank and Rasheed Bank are the Iraq's three biggest state banks that hold $87 \%$ of the whole financial part's advantages ${ }^{1}$. From this, the future prospects of ATM services tasks can be broke down.

Customer satisfaction and Services offered has always been a hot topic for the researchers to do their research work. With the advent of technology in banking system, it is expected that the customers would not face any hassle during the financial transaction. Coming to ATMs, there are working burden of ATM machines and routinely there are issues looked by customers while utilizing the ATM machines, for example, not providing the 
money, charge exchange when money isn't apportioned, card stuck in the ATM, unfit to pull back money with found ATM and so on. As the users of ATM is expanding every day. It is essential to make an investigation to pick up understanding about the consumer satisfaction level concerning different parts of ATM services offered to them. With this problem, the researchers would like to investigate on the Satisfaction Level with the ATM services provided to them. Thus, the first objective for this research work becomes to investigate the consequences of various ATM service quality dimensions on customer satisfaction. And secondly to suggest recommendations based on research.

\section{LITERATURE REVIEW}

Previous researches are evident that ATM is an autoelectronic cabin where the customers visit it to make monetary transactions, be it cash dispensing, depositing or balance inquiry. Santos (2003) stated that ATM service quality is the clients' general assessment and prudence of the brilliance of services gave through ATM channels. Narteh (2013) opined that ATM quality dimensions have several dimensional and these dimensions are Trust/Reliability, Convenient, Easiness in use, Security and Privacy, Fulfillment, and Responsiveness.

Wolfinbarger and Gilly (2003) claimed of trust/reliability to be hearty translator of buyers loyalty in electronic channels. The reliability measurement is basic since it inserts the dynamic competency to play out the embraced administration constantly and precisely. In the ATM condition, dependability predicts the limit of the machine to work always, and give mistake free and steady administrations.

Narteh $(2015,2013)$ opined that Conveniences is regarded as the area or site of the ATM and includes $24 / 7$ accessibility of the services to the customers. Al-Hawari et al., (2009) stated that convenience has been the most utilized element of ATM administration quality and has been observed to be decidedly identified with consumer satisfaction.

Gounaris and Koritos, (2008), examine utilizes the idea to mean how much ATMs offer inconvenience free exchange for the client. Viability is a key component in characterizing the acknowledgment and use of various data advancements, for example, web based banking. Analysts, for example, Al-Hawari et al. (2009) found that Ease of use prompts consumer satisfaction in case of ATM utilization.

Chong et al. (2010) uncover in Vietnam that security and protection as significant factors in the reception of E-banking. Each client anticipates insurance for their cash and individual data from their banks. In the studies of USA, Australia, and Pakistan, security and privacy were considered as important ATM service quality dimensions (Joseph and Stone, 2003; Al-Hawari et al., 2009. Subsequently, the present examination accepts that security and protection will be decidedly related to consumer satisfaction.

The satisfaction of sites affects all out quality, fulfillment, and dedication expectations (Wolfinbarger and Gilly 2003). Past investigations identified with ATM thought about satisfaction as a quality dimension to gauge result allure or how much the ATM performs results to meet the clients' desires. This incorporates the justifiability of notes given by the ATM (destroy fakes); the aggregate provided for customers per trade, and the ATM's esteem based charges forced on clients. Narteh (2015) discovered the accessibility of money and the quality of money to be significant ATM service quality factors.

Like all advancements, ATMs are likewise once in a while arranged to support disappointments. Responsiveness estimates the achievement of methodologies which the banks acquaint with show signs of improved services when ATM services are unfortunately settled (Narteh 2015). Responsiveness or recuperation is a noteworthy determinant in numerous electronic service quality scales (Parasuraman et al., 2005; Nambirajan and Prabhu 2010 Narteh 2013; 2015). Narteh (2015) expressed that compelling ATM reaction procedures envision consumer loyalty in Pakistan.

A client is said to be loyal to a brand that gives an attractive experience. Berrli et al., (2004) expressed that fulfillment has been appeared to have its impact on client loyalty and the reason that fulfillment together with close to home exchanging costs are forerunners of 
reliability. Some researcher's points out that Satisfaction and loyalty are connected. Satisfaction is, thusly, a component of the overall dimension of desire and perceived execution. Desires are based on past involvement with the equivalent or comparative circumstances, explanations made by friends, or different partners (Oliver 1999; Prabhu et al., 2019)

Expanding on the current literature changed over, the present investigation recommends that Reliability, Convenience, Ease of use, Security and privacy, Responsiveness, and Fulfillment are anticipated to be the central elements of ATM service quality which will affect consumer loyalty and impact customer satisfaction. Thus, the following research framework is drafted.

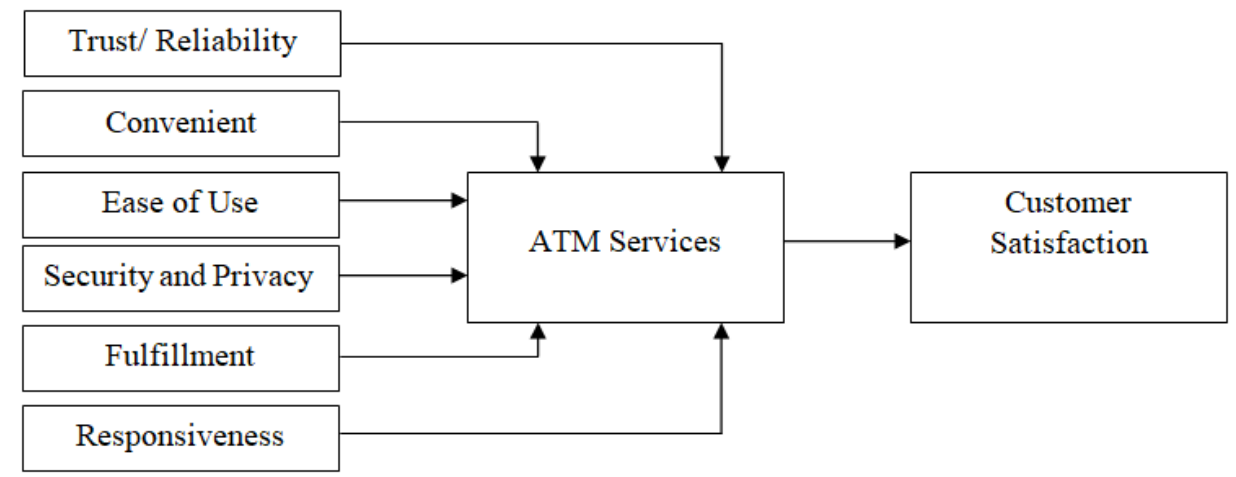

Figure 1 - Research Framework

\section{METHODS OF RESEARCH}

To investigate on ATM service quality impact on customer satisfaction, primary data were collected through structured questionnaire. Questionnaire was designed after deep study of many research papers. To document the respondents' opinion on ATM services fivepoint Likert-type questionnaires were used as a survey instrument (Ranging from "Strongly Agree" (5) to "Strongly Disagree" (1).

The things utilized for the review instrument were embraced from before studies and the estimations taken are referenced in Table 2. The Questionnaire was based on two parts: one was related to demographic profile of respondents and the other was based on constructs. After compilation of the questionnaire, it was circulated among the respondents in both hard copy and soft copy form. A Simple Random convenience sampling method was implemented. A total of 230 questionnaires were distributed, but 211 usable completed questionnaires were received making the response rate to be $91.73 \%$.

Data were collected from ATM users of different places of Kurdistan region.

Descriptive analysis, correlation analysis, reliability analysis was performed to assess the inner consistency of the things. Regression and ANOVA test performed to evaluate hypothesis testing by the help of IBM SPSS 25.0.

\section{RESULTS AND DISCUSSION}

Table 1 describes the demographic profile of respondents. In this research $54.5 \%$ male and $45.5 \%$ female participated. Majority of respondents were between 20-30 years i.e. $68.2 \%, 15.1 \%$ belongs to below 20 years, $8.6 \%$ between 30 to 40 years and $8.1 \%$ were from $41-50$ years. Maximum respondents i.e. $37.7 \%$ are graduate, $30.3 \%$ are post graduate and $31.7 \%$ were under graduate. Maximum i.e. $46.4 \%$ are salaried employed, $30.3 \%$ are students, $23.2 \%$ are self employed. Maximum i.e. $31.3 \%$ respondents income level belongs to $\$ 1001$ to $\$ 1500$, then $22.8 \%$ between $\$ 501$ to $\$ 1000$, then $15.6 \%$ below $\$ 500$ and $7.5 \%$ for both between $\$ 2001$ to $\$ 2500$ and $\$ 2500$ to $\$ 2500$. It is quite disappointed that $37.9 \%$ respondents use their ATM card for balance enquiry and only $24.1 \%$ use for cash withdrawal. 
Bank must have to pay attention towards this. $32.7 \%$ responds opinion is ATM is easy banking any time anywhere but only $9.9 \%$ respondents says it means for faster transactions.

Table 1 - Demographics Profile of the Respondents (\%)

\begin{tabular}{|c|c|c|c|}
\hline & $n / n$ & Frequency & Percent \\
\hline \multirow[t]{2}{*}{ Gender } & Male & 115 & 54.5 \\
\hline & Female & 96 & 45.5 \\
\hline \multirow[t]{4}{*}{ Age (in years) } & Below 20 years & 32 & 15.1 \\
\hline & $20-30$ years & 144 & 68.2 \\
\hline & $30-40$ years & 18 & 8.6 \\
\hline & $41-50$ years & 17 & 8.1 \\
\hline \multirow[t]{3}{*}{ Education Qualification } & Under Graduate & 67 & 31.7 \\
\hline & Graduate & 80 & 37.9 \\
\hline & Post Graduate and above & 64 & 30.3 \\
\hline \multirow[t]{3}{*}{ Occupation/ Economic Activity } & Student & 64 & 30.3 \\
\hline & Salaried Employed & 98 & 46.4 \\
\hline & Self employed & 49 & $\frac{70.7}{23.2}$ \\
\hline \multirow[t]{6}{*}{ Family Monthly Income } & Below $\$ 500$ & 33 & 15.6 \\
\hline & Between $\$ 501$ to $\$ 1000$ & 48 & 22.8 \\
\hline & Between $\$ 1001$ to $\$ 1500$ & 66 & 31.3 \\
\hline & Between $\$ 1501$ to $\$ 2000$ & 32 & 15.2 \\
\hline & Between $\$ 2001$ to $\$ 2500$ & 16 & 7.5 \\
\hline & Above $\$ 2500$ & 16 & 7.5 \\
\hline \multirow[t]{4}{*}{ Purpose of using ATM card } & Cash withdrawal & 51 & 24.1 \\
\hline & Balance Check & 80 & 37.9 \\
\hline & Shopping & 48 & 22.7 \\
\hline & Other & 32 & 15.1 \\
\hline \multirow[t]{6}{*}{ Reason to preference of ATM } & Easy banking any time any where & 69 & 32.7 \\
\hline & Easy to use & 32 & 15.2 \\
\hline & Faster transactions & 21 & 9.9 \\
\hline & Time saving & 48 & 22.7 \\
\hline & All of above & 41 & 19.4 \\
\hline & Total & 211 & 100 \\
\hline
\end{tabular}

Table 2 - Exploratory Factor Analysis

\begin{tabular}{|c|c|c|}
\hline Items & Adapted Source & Factor Loadings \\
\hline \multicolumn{3}{|l|}{ RELIABILITY Cronbach's Alpha $=.802$} \\
\hline ATM works constantly. & \multirow{2}{*}{ Narteh, (2015) } & .965 \\
\hline ATM provides consistent services. & & .959 \\
\hline I don't discover counterfeit money notes from my ATM. & \multirow{2}{*}{ Jha et al. , (2014) } & .981 \\
\hline I never found my ATM out of cash. & & .927 \\
\hline \multicolumn{3}{|l|}{ CONVENIENCE Cronbach's Alpha $=.754$} \\
\hline ATMs are conveniently located in my city. & Narteh, (2015) & .924 \\
\hline ATMs of my bank are easily found at all useful places like hospitals, malls, airports \&amp; stations etc. & Jha et al. , (2014) & .885 \\
\hline I can locate my bank's ATMs easily when I am out of station. & \multirow{2}{*}{ Narteh, (2015) } & .735 \\
\hline ATM cards are perfect on different stages. & & .899 \\
\hline \multicolumn{3}{|l|}{ EASE OF USE Cronbach's Alpha $=.840$} \\
\hline ATM gives clear directions on use. & \multirow{4}{*}{ Narteh, (2015) } & .942 \\
\hline ATMs are user friendly for transactions. & & .927 \\
\hline Language of ATM is easy. & & .973 \\
\hline ATM gives illustrations and adverts of bank administrations. & & .964 \\
\hline \multicolumn{3}{|l|}{ SECURITY AND PRIVACY Cronbach's Alpha $=.700$} \\
\hline I can rely and have belief in the security of ATM Banking. & \multirow{2}{*}{ Narteh, (2015) } & .959 \\
\hline I feel safe amid ATM exchanges. & & .981 \\
\hline I believe in the security of my own data. & \multirow{2}{*}{ Collier, (2006) } & .927 \\
\hline I trust that Bank ATM will not misuse my personal information. & & .971 \\
\hline \multicolumn{3}{|l|}{ FULFILLMENT Cronbach's Alpha $=.696$} \\
\hline ATM provides fast services. & \multirow{5}{*}{ Narteh, (2015) } & .965 \\
\hline ATM gives enough cash amid exchanges. & & .959 \\
\hline ATM fulfills the majority of my financial needs. & & .981 \\
\hline ATM charges are sensible. & & .927 \\
\hline ATM gives instant money all the time. & & .971 \\
\hline \multicolumn{3}{|l|}{ RESPONSIVENESS Cronbach's Alpha $=.821$} \\
\hline ATM contact person is available to set right the problems. & \multirow{2}{*}{ Narteh, (2015) } & .836 \\
\hline ATM Broken-down are promptly fixed. & & .927 \\
\hline ATM cards are speedily replaced. & & .973 \\
\hline ATM banking is able to settle complaints in a very short time. & & .938 \\
\hline \multicolumn{3}{|l|}{ CUSTOMER SATISFACTION Cronbach's Alpha $=.786$} \\
\hline My bank's ATMs provide me all the service that I need. & \multirow{2}{*}{ Cockrill et al., (2009) } & .959 \\
\hline Generally speaking, I am exceptionally happy with the services an ATM gives me. & & .976 \\
\hline I like to urge family, friends and relatives to utilize an ATM machine worked by this bank. & \multirow{2}{*}{ Casalo et al., (2008) } & .918 \\
\hline I imagine that I settled on the right choice to utilize this current bank's ATM & & .768 \\
\hline \multicolumn{3}{|l|}{ CUSTOMER LOYALTY Cronbach's Alpha $=.759$} \\
\hline I have a positive passionate association with the bank's ATM I have picked. & \multirow{2}{*}{ Eakuru and Matt, (2008) } & .879 \\
\hline I intend to remain a user of the bank's ATM I have chosen. & & .928 \\
\hline I would dependably prescribe my bank's ATM to somebody who looks for my recommendation. & Beerli et al., (2004) & .859 \\
\hline $\begin{array}{l}\text { In light of my experience, I am in all respects prone to proceed with my association with this present bank's ATM in } \\
\text { the following months. }\end{array}$ & Casalo et al., (2008) & .906 \\
\hline
\end{tabular}

The Cronbach's alpha reliability test has been utilized to distinguish the items utilized in review. From the table no. 2 Cronbach's alpha for group variables of Reliability (.802), Convenience (.754), Ease of use (.840), Security and Privacy (.700), Fulfillment (.696), Responsiveness (.821), Customer Satisfaction (.786) and Customer Loyalty (.759). 
To check the dimensionality of the instrument, all the items of the questionnaire were factor analyzed by using varimax rotation. The validation process was initiated with an underlying exploratory examination of reliability and dimensionality. Values of test of Bartlett test of sphericity and Kaiser-Meyer-Olkin (KMO) unwavering quality and dimensionality. and the group and individual's variable have more than .700 up to .981 , it means they are highly reliable variable for further research.

Table 3 shows total number of Respondents, its Means and Standard Deviation of respondents. The table shows the extent to which the participated respondents agreed/disagreed with the questions. The highest mean was 4.85 (I don't discover counterfeit money notes from my ATM, I feel safe during ATM transactions and thirdly ATM fulfills the majority of my financial needs.) and 4.15 (I trust that Bank ATM will not misuse my personal information and ATM gives instant money all the time) while least was 2.54 (ATM gives illustrations and adverts of bank administrations).

Table 3 - Descriptive Statistics

\begin{tabular}{|c|c|c|c|}
\hline $\mathrm{n} / \mathrm{n}$ & $\mathrm{N}$ & Mean & Std. Deviation \\
\hline ATM works constantly. & 211 & 2.77 & .893 \\
\hline ATM provides consistent services. & 211 & 3.08 & 1.074 \\
\hline I don't discover counterfeit money notes from my ATM. & 211 & 4.85 & .534 \\
\hline I never found my ATM out of cash. & 211 & 3.31 & .823 \\
\hline ATMs are conveniently located in my city. & 211 & 3.38 & .626 \\
\hline $\begin{array}{l}\text { ATMs of my bank are easily found at all useful places like hospitals, } \\
\text { malls, airports \&amp; stations etc. }\end{array}$ & 211 & 3.38 & .626 \\
\hline I can locate my bank's ATMs easily when I am out of station. & 211 & 3.38 & .626 \\
\hline ATM cards are perfect on different stages. & 211 & 3.08 & .617 \\
\hline ATM gives clear directions on use. & 211 & 3.46 & .845 \\
\hline ATMs are user friendly for transactions. & 211 & 3.69 & 1.068 \\
\hline Language of ATM is easy. & 211 & 3.46 & .932 \\
\hline ATM gives illustrations and adverts of bank administrations. & 211 & 2.54 & .845 \\
\hline I can rely and have confidence in the security of ATM Banking. & 211 & 3.08 & 1.074 \\
\hline I feel safe during ATM transactions. & 211 & 4.85 & .534 \\
\hline I believe in the security of my own data. & 211 & 3.31 & .823 \\
\hline I trust that Bank ATM will not misuse my personal information. & 211 & 4.15 & .362 \\
\hline ATM provides fast services. & 211 & 2.77 & .893 \\
\hline ATM gives enough cash amid exchanges. & 211 & 3.08 & 1.074 \\
\hline ATM fulfills the majority of my financial needs. & 211 & 4.85 & .534 \\
\hline ATM charges are sensible. & 211 & 3.31 & .823 \\
\hline ATM gives instant money all the time. & 211 & 4.15 & .362 \\
\hline ATM Contact person is available to set right the problems & 211 & 3.38 & .838 \\
\hline ATM Broken-down are promptly fixed. & 211 & 3.69 & 1.068 \\
\hline ATM cards are speedily replaced. & 211 & 3.46 & .932 \\
\hline ATM banking is able to settle complaints in a very short time. & 211 & 3.23 & .893 \\
\hline My bank's ATMs provide me all the service that I need. & 211 & 3.38 & .626 \\
\hline Generally speaking, I am exceptionally happy with the services an ATM gives me. & 211 & 3.38 & .626 \\
\hline I like to urge family, friends and relatives to utilize an ATM machine worked by this bank. & 211 & 3.38 & .626 \\
\hline I imagine that I settled on the right choice to utilize this current bank's ATM & 211 & 3.15 & .534 \\
\hline I have a positive passionate association with the bank's ATM I have picked. & 211 & 3.69 & .463 \\
\hline I intend to remain a user of the bank's ATM I have chosen. & 211 & 3.77 & .422 \\
\hline I would dependably prescribe my bank's ATM to somebody who looks for my recommendation. & 211 & 3.69 & .463 \\
\hline $\begin{array}{l}\text { In light of my experience, I am in all respects prone to proceed with my association } \\
\text { with this present bank's ATM in the following months. }\end{array}$ & 211 & 3.31 & .723 \\
\hline Valid N (listwise) & \multicolumn{3}{|c|}{211} \\
\hline
\end{tabular}

Connection between Service Quality and Comprehensive Customer Satisfaction:

- $\mathrm{H}_{01}$ : There is no critical connection between overall service quality dimensions and clients' satisfaction in ATM service;

- $\mathrm{H}_{\mathrm{a} 1}$ : There is critical connection between overall service quality dimensions and clients' satisfaction in ATM service.

Dilijonas et al., (2009) and Komal \& Singh, (2009) found that that service quality has critical connection with overall customers satisfaction in ATM service. However, the present research does not fully support this. Table no. 4 indicates that from all dimensions four dimensions are significantly correlated with overall customer satisfaction and three dimensions are not significantly correlated. Easy to use, Reliability and Convenience are correlated and is significant at the 001 level (2 tailed), Fulfillment is correlated at 0.05 level. Whereas, Responsiveness, Security \& Privacy, and Customer Loyalty are not in significant level with overall customer satisfaction. 
Table 4 - Correlations

\begin{tabular}{|c|c|c|c|c|c|c|c|c|c|}
\hline \multicolumn{2}{|l|}{$n / n$} & Reliability & Convenience & Easy_to_use & $\begin{array}{l}\text { Security } \\
\text { Privacy }\end{array}$ & Fulfillment & Responsiveness & $\begin{array}{l}\text { Customer } \\
\text { Satisfaction }\end{array}$ & Custome \\
\hline \multirow{3}{*}{ Reliability } & $\begin{array}{c}\text { Pearson } \\
\text { Correlation }\end{array}$ & 1 & $-.412^{* *}$ & $.779^{* *}$ & $.924^{* *}$ & $.990 *$ & $.823^{* *}$ & $.252^{* *}$ & $.430^{* *}$ \\
\hline & Sig. (2-tailed) & & .000 & .000 & .000 & .000 & .000 & .000 & .000 \\
\hline & $N$ & 211 & 211 & 211 & 211 & 211 & 211 & 211 & 211 \\
\hline \multirow{3}{*}{ Convenience } & $\begin{array}{c}\text { Pearson } \\
\text { Correlation }\end{array}$ & $-.412^{* *}$ & 1 & $-.288^{* *}$ & $-.191^{* *}$ & $-.321^{* *}$ & $-.355^{* *}$ & $-.278^{* *}$ & $-.392^{* *}$ \\
\hline & Sig. (2-tailed) & .000 & & .000 & .006 & .000 & .000 & .000 & .000 \\
\hline & $\mathrm{N}$ & 211 & 211 & 211 & 211 & 211 & 211 & 211 & 211 \\
\hline \multirow{3}{*}{ Easy_to_use } & $\begin{array}{l}\text { Pearson } \\
\text { Correlation }\end{array}$ & $.779^{* *}$ & $-.288^{* *}$ & 1 & $.716^{* *}$ & $.797^{* *}$ & $.945^{* *}$ & $.192^{* *}$ & $.699^{* *}$ \\
\hline & Sig. (2-tailed) & .000 & .000 & & .000 & .000 & .000 & .005 & .000 \\
\hline & $\mathrm{N}$ & 211 & 211 & 211 & 211 & 211 & 211 & 211 & 211 \\
\hline \multirow{3}{*}{ Security_Privacy } & $\begin{array}{l}\text { Pearson } \\
\text { Correlation }\end{array}$ & $.924 *$ & $-.191^{* *}$ & $.716^{* *}$ & 1 & $.946^{* *}$ & $.802^{* *}$ & .027 & $.371^{* *}$ \\
\hline & Sig. (2-tailed) & .000 & .006 & .000 & & .000 & .000 & .695 & .000 \\
\hline & N & 211 & 211 & 211 & 211 & 211 & 211 & 211 & 211 \\
\hline \multirow{3}{*}{ Fulfillment } & $\begin{array}{c}\text { Pearson } \\
\text { Correlation }\end{array}$ & $.990^{* *}$ & $-.321^{* *}$ & $.797^{* *}$ & $.946^{* *}$ & 1 & $.849^{* *}$ & $.162^{*}$ & $.427^{* *}$ \\
\hline & Sig. (2-tailed) & .000 & .000 & .000 & .000 & & .000 & .019 & .000 \\
\hline & $\mathrm{N}$ & 211 & 211 & 211 & 211 & 211 & 211 & 211 & 211 \\
\hline \multirow{3}{*}{ Responsiveness } & $\begin{array}{l}\text { Pearson } \\
\text { Correlation }\end{array}$ & $.823^{* *}$ & $-.355^{* *}$ & $.945^{* *}$ & $.802^{* *}$ & $.849^{* *}$ & 1 & .053 & $.580^{*+}$ \\
\hline & Sig. (2-tailed) & .000 & .000 & .000 & .000 & .000 & & .449 & .000 \\
\hline & $\mathrm{N}$ & 211 & 211 & 211 & 211 & 211 & 211 & 211 & 211 \\
\hline \multirow{3}{*}{ Customer_Satisfaction } & $\begin{array}{c}\text { Pearson } \\
\text { Correlation }\end{array}$ & $.252^{* *}$ & $-.278^{* *}$ & $.192^{* *}$ & .027 & $.162^{*}$ & .053 & 1 & -.021 \\
\hline & Sig. (2-tailed) & .000 & .000 & .005 & .695 & .019 & .449 & & .758 \\
\hline & $\mathrm{N}$ & 211 & 211 & 211 & 211 & 211 & 211 & 211 & 211 \\
\hline \multirow{3}{*}{ Customer_Loyalty } & $\begin{array}{c}\text { Pearson } \\
\text { Correlation }\end{array}$ & $.430 *$ & $-.392^{* *}$ & $.699^{* *}$ & $.371^{*+}$ & $.427^{* *}$ & $.580^{* *}$ & -.021 & 1 \\
\hline & Sig. (2-tailed) & .000 & .000 & .000 & .000 & .000 & .000 & .758 & \\
\hline & $\mathrm{N}$ & 211 & 211 & 211 & 211 & 211 & 211 & 211 & 211 \\
\hline
\end{tabular}

Therefore:

- $\mathrm{H}_{01}$ was accepted in case of Responsiveness, Security \& Privacy and Customer Loyalty;

- $\mathrm{H}_{\mathrm{a} 1}$ was accepted in case of Easy to Use, Reliability, Convenience and Fulfillment criteria.

Hypothesis:

- H01 (Null Hypothesis): Customer satisfaction is not dependent on responsiveness;

- Ha1 (Alternative Hypothesis): Customer satisfaction is dependent on responsiveness;

- H02 (Null Hypothesis): Customer satisfaction is not dependent on easy to use;

- Ha2 (Alternative Hypothesis): Customer satisfaction is dependent on easy to use;

- H03 (Null Hypothesis): Customer satisfaction is not dependent on reliability;

- Ha3 (Alternative Hypothesis): Customer satisfaction is dependent on reliability;

- H04 (Null Hypothesis): Customer satisfaction is not dependent on convenience;

- Ha4 (Alternative Hypothesis): Customer satisfaction is dependent on convenience;

- H05 (Null Hypothesis): Customer satisfaction is not dependent on fulfillment;

- Ha5 (Alternative Hypothesis): Customer satisfaction is dependent on fulfillment;

- H06 (Null Hypothesis): Customer satisfaction is not dependent on security and privacy;

- Ha6 (Alternative Hypothesis): Customer satisfaction is dependent on security and privacy;

- H07 (Null Hypothesis): Customer satisfaction is not dependent on customer loyalty;

- Ha7 (Alternative Hypothesis): Customer satisfaction is dependent on customer loyalty.

Model:

The authors have used the overall customer satisfaction as the dependent variable and others dimensions modified in groups like - responsiveness, easy to use, reliability, convenience, fulfillment, security and privacy and customer loyalty as the independent variables.

The Regression model as follows: 
Where: $Y=$ Overall Customer Satisfaction; $X_{1}=$ Responsiveness; $X_{2}=$ Easy to use; $\mathrm{X}_{3}=$ Reliability; $\mathrm{X}_{4}=$ Convenience; $\mathrm{X}_{5}=$ Fulfillment; $\mathrm{X}_{6}=$ Security and privacy; $\mathrm{X}_{7}=$ Customer loyalty; $\mathrm{e}_{\mathrm{i}}=$ Error.

The overall regression model and its ANOVA are summarized as follows:

Table 5 - Model Summary

\begin{tabular}{|c|c|c|c|c|c|c|c|c|c|}
\hline \multirow[b]{2}{*}{ Model } & \multirow[b]{2}{*}{$\mathrm{R}$} & \multirow[b]{2}{*}{$\begin{array}{c}\mathrm{R} \\
\text { Square }\end{array}$} & \multirow[b]{2}{*}{$\begin{array}{l}\text { Adjusted R } \\
\text { Square }\end{array}$} & \multirow[b]{2}{*}{$\begin{array}{l}\text { Std. Error of the } \\
\text { Estimate }\end{array}$} & \multicolumn{5}{|c|}{ Change Statistics } \\
\hline & & & & & $\begin{array}{l}\text { R Square } \\
\text { Change }\end{array}$ & $\begin{array}{c}\mathrm{F} \\
\text { Change } \\
\end{array}$ & df1 & df2 & $\begin{array}{c}\text { Sig. F } \\
\text { Change }\end{array}$ \\
\hline 1 & $.883^{\mathrm{a}}$ & .780 & .772 & .90711 & .780 & 101.345 & 7 & 200 & .000 \\
\hline \multicolumn{10}{|c|}{$\begin{array}{l}\text { a. Predictors: (Constant), Customer_Loyalty, Security_Privacy, Convenience, Easy_to_use, Reliability, Responsiveness, } \\
\text { Fulfillment }\end{array}$} \\
\hline
\end{tabular}

Table 6 - ANOVA $^{\mathrm{a}}$

\begin{tabular}{|c|c|c|c|c|c|c|}
\hline \multicolumn{2}{|c|}{ Model } & Sum of Squares & df & Mean Square & $\mathrm{F}$ & Sig. \\
\hline \multirow{3}{*}{1} & Regression & 583.739 & 7 & 83.391 & 101.345 & $.000^{6}$ \\
\hline & Residual & 164.569 & 200 & .823 & & \\
\hline & Total & 748.308 & 207 & & & \\
\hline \multicolumn{7}{|c|}{ a. Dependent Variable: Customer_Satisfaction } \\
\hline
\end{tabular}

Table 7 - Coefficients ${ }^{\mathrm{a}}$

\begin{tabular}{|c|c|c|c|c|c|c|}
\hline & \multirow{2}{*}{ Model } & \multicolumn{2}{|c|}{ Unstandardized Coefficients } & \multirow{2}{*}{$\begin{array}{c}\text { Standardized Coefficients } \\
\text { Beta }\end{array}$} & \multirow{2}{*}{$\mathrm{t}$} & \multirow{2}{*}{ Sig. } \\
\hline & & $B$ & Std. Error & & & \\
\hline \multirow{8}{*}{1} & (Constant) & 31.182 & 1.429 & & 21.819 & .000 \\
\hline & Responsiveness & -.588 & .143 & -.935 & -4.122 & .000 \\
\hline & Easy_to_use & .963 & .136 & 1.540 & 7.073 & .000 \\
\hline & Reliability & 4.271 & .405 & 5.791 & 10.541 & .000 \\
\hline & Convenience & .222 & .101 & .221 & 2.206 & .029 \\
\hline & Fulfillment & -3.906 & .377 & -5.349 & -10.370 & .000 \\
\hline & Security_privacy & -.332 & .130 & -.379 & -2.552 & .011 \\
\hline & Customer_loyalty & -.632 & .084 & -.533 & -7.523 & .000 \\
\hline & & & Variable & sfaction & & \\
\hline
\end{tabular}

Table 8 - Hypothesis Testing

\begin{tabular}{|c|c|c|c|}
\hline Path & Significance & Hypothesis accepted & Remark \\
\hline $\begin{array}{l}\text { Responsiveness to customer } \\
\text { satisfaction }\end{array}$ & .000 & $\begin{array}{l}\text { Ha1 (Alternative } \\
\text { Hypothesis) }\end{array}$ & $\begin{array}{c}\text { Customer satisfaction is dependent on } \\
\text { responsiveness. }\end{array}$ \\
\hline $\begin{array}{c}\text { Easy to use to customer } \\
\text { satisfaction }\end{array}$ & .000 & $\begin{array}{l}\text { Ha2 (Alternative } \\
\text { Hypothesis) }\end{array}$ & $\begin{array}{c}\text { Customer satisfaction is dependent on easy to } \\
\text { use }\end{array}$ \\
\hline Reliability to customer satisfaction & .000 & $\begin{array}{l}\text { Ha3 (Alternative } \\
\text { Hypothesis): }\end{array}$ & $\begin{array}{c}\text { Customer satisfaction is dependent on } \\
\text { reliability. }\end{array}$ \\
\hline $\begin{array}{l}\text { Convenience to customer } \\
\text { satisfaction }\end{array}$ & .000 & $\begin{array}{l}\text { Ha4 (Alternative } \\
\text { Hypothesis): }\end{array}$ & $\begin{array}{c}\text { Customer satisfaction is dependent on } \\
\text { convenience. }\end{array}$ \\
\hline Fulfillment to customer satisfaction & .029 & H05 (Null Hypothesis) & $\begin{array}{l}\text { Customer satisfaction is not dependent on } \\
\text { fulfillment. }\end{array}$ \\
\hline $\begin{array}{l}\text { Security and privacy to customer } \\
\text { satisfaction }\end{array}$ & .000 & $\begin{array}{l}\text { Ha6 (Alternative } \\
\text { Hypothesis) }\end{array}$ & $\begin{array}{l}\text { Customer satisfaction is dependent on } \\
\text { security and privacy. }\end{array}$ \\
\hline $\begin{array}{l}\text { Customer loyalty to customer } \\
\text { satisfactions }\end{array}$ & .011 & H07 (Null Hypothesis) & $\begin{array}{c}\text { Customer satisfaction is not dependent on } \\
\text { customer loyalty }\end{array}$ \\
\hline
\end{tabular}

From the above ANOVA test table no. 6 significance level is .000 and calculated value of ANOVA is 101.345 is greater than the critical value. Hence, it is proved that null hypothesis is rejected. It shows that alternative hypothesis is accepted. Its means that there is a significance relation between the customer satisfaction and various dimensions of ATM services.

From table no. 5 of model summary, it can be concluded that all mentioned dimensions of ATM services have $78 \%$ impact on overall customer satisfaction which can be considered a high significance impact.

Here, the value of $R=.883$. There is a high volume of positive correlation among the independent and dependent variables. 
Value of $\mathrm{R}^{2}=.780$ or $78.0 \%$ or $78 \% .78 \%$ variation in the dependent variables can be concluded by the regression model.

Adjusted $\mathrm{R}^{2}=.772$ or $77.2 \%$ or $77 \%$.

The Regression Equation:

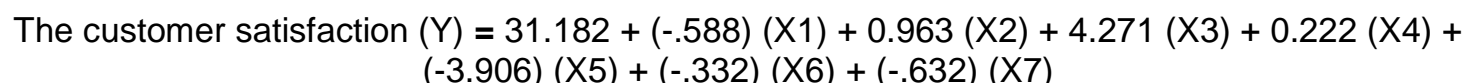

\section{CONCLUSION AND RECOMMENDATIONS}

After this research it can be concluded that a) maximum respondents are youngsters $b$ ) maximum are graduated $c$ ) they mould into moderate income class $d$ ) but respondents they use ATM for balance enquiry and in comparison lesser in cash withdrawal and online shopping which is point of concern e) when respondents says ATM is easy banking any time anywhere so why they do use only for only two times or three times only? It is because they do not have trust on online payment and trust more on agencies $f$ ) if we look at each and every dimension of ATM service (Table 2) it is observed that there is very significant difference in opinion of respondents. Because of population is growing up banking industry have vide scope in future. Banking industry must earn the confidence of the respondents by providing safer transaction; do the changes after doing pilot survey and taking opinion of the respondents.

This research is carried out in different places of Erbil city. The result is based on information provided by the respondents. Because of time constraints maximum populations could not be traced. Different places may have different opinion.

\section{REFERENCES}

1. Electronic Source: https://investingroup.org/review/237/reform-investment-financekurdistan/

2. Al-Hawari, M., Ward, T., \& Newby, L. (2009). The relationship between service quality and retention within the automated and traditional contexts of retail banking. Journal of service Management, 20 (4), 455-472.

3. Beerli, A., Martin, J. D., \& Quintana, A. (2004). A model of customer loyalty in the retail banking market. European Journal of Marketing, 38 (1/2), 253-275.

4. Casalo, L. V., Flavián, C., \&Guinalíu, M. (2008). The role of satisfaction and website usability in developing customer loyalty and positive word-of-mouth in the e-banking services. International Journal of Bank Marketing, 26 (6), 399-417.

5. Chong, A. Y.-L., Ooi, K.-B., Lin, B. and Tan, B.-I. (2010) Online Banking Adoption: An Empirical Analysis. International Journal of Bank Marketing, 28 (4): 267-287.

6. Cockrill, A., Goode, M. M., \& Beetles, A. (2009). The critical role of perceived risk and trust in determining customer satisfaction with automated banking channels. Services Marketing Quarterly, 30 (2), 174-193.

7. Collier, J. E., \&Bienstock, C. C. (2006).Measuring Service Quality in E-Retailing. Journal of Service Research, 8 (3), 260-275

8. Dilijonas, D, K., D., Sakalauskas, V. \& Simutis, R. (2009). Sustainability Based Service Quality Approach for Automated Teller Machine Network, Electronic copy available on http://www.vgtu.It/leidiniai/ leidykla/ KORSD_2009/PDF/241- 246-p100-Dilijonas-47.pdf

9. Dixit, P., \& Tyagi, A. (2015). A Study of Downturn Trends of Crude Oil Price-An Economic Advantage for Indian Government and Consumers, Int. J. of Trade and Commerce-IIARTC, 4 (1), 121-126

10. Eakuru, N., \& Mat, N. K. N. (2008). The application of structural equation modeling (SEM) in determining the antecedents of customer loyalty in banks in South Thailand. The Business Review, Cambridge, 10 (2), 129-139. 
11. Gounaris, S., \& Koritos, C. (2008). Investigating the drivers of internet banking adoption decision: A comparison of three alternative frameworks. International Journal of Bank Marketing, 26 (5), 282-304.

12. Jha, B. K.; Sureka, S.; Shitika. 2014. Customer's satisfaction for ATM services in Bihar, India, International Journal of Interdisciplinary and Multidisciplinary Studies, 1 (4): 42-49.

13. Joseph, M., \& Stone, G. (2003). An empirical evaluation of US bank customer perceptions of the impact of technology on service delivery in the banking sector. International Journal of Retail \& Distribution Management, 31 (4), 190-202.

14. Komal, Singh, S. (2009). Impact of ATM on Customer Satisfaction (A Comparative Study of SBI, ICICI \& HDFC bank). Business Intelligence Journal - August, 2 (2), 276-87

15. Narteh, B. (2013). Service quality in automated teller machines: an empirical investigation. Managing Service Quality: An International Journal, 23 (1), 62-89.

16. Narteh, B. (2015). Perceived service quality and satisfaction of self-service technology: The case of automated teller machines. International Journal of Quality \& Reliability Management, 32 (4), 361-380.

17. Nambirajan, T., \& Prabhu, M. (2010). Determinants of Competitiveness of Small-Scale Industries in Union Territory of Puducherry.Advances in Management, 3 (5), 46-49.

18. Oliver, R. L. (1999). A cognitive model of the antecedents and consequences of satisfaction decisions. Journal of marketing research, 460-469.

19. Parasuraman, A., Zeithaml, V.A. and Malholtra, A. (2005), "E-S-QUAL: a multiple-item scale for assessing electronic service quality", Journal of Service Research, Vol. 7 No. 3, pp. 213-235.

20. Prabhu, M., Nabaz Nawzad Abdullah and Madan Mohan, G. (2019), An Empirical Study on the Satisfaction Level of National and International Tourists towards Natural Attractions in Kurdistan. African Journal of Hospitality, Tourism and Leisure, Volume 8 (2), 1-8.

21. Santos, J. (2003). E-service quality: a model of virtual service quality dimensions. Managing Service Quality: An International Journal, 13 (3), 233-246.

22. Wolfinbarger, M., \& Gilly, M. C. (2003). eTailQ: Dimensionalizing, Measuring and Predicting Retail quality. Journal of retailing, 79 (3), 183-198. 